Vol. 40(2), pp. 33-44, Dec. 2021

ISSN 1821-536X (print)

ISSN 2619-8789 (electronic)
Tanzania Journal of Engineering and Technology

Copyright $(\subset) 2021$ College of Engineering and

Technology, University of Dar es Salaam

Full Length Research Paper

\title{
Development of Intensity-Duration-Frequency (IDF) Models for Manually Operated Rain Gauge Catchment: A Case Study of Port Harcourt Metropolis Using 50 Years Rainfall Data
}

\author{
Francis James Ogbozige
}

Department of Civil Engineering, Federal University Otuoke, Nigeria

Corresponding Email: engr.ogbozige@gmail.com

\begin{abstract}
Hydraulic structures such as surface drainages and culverts are usually constructed in urban areas with the intention of draining runoff into nearby streams and rivers in order to avoid flooding. However, most of these structures frequently fail to serve the intended use due to the occurrence of high intensity rainfall accompanied with long duration, which produce runoff discharge higher than their designed capacities. This is common in many developing countries as drainages and culverts are most times constructed without considering hydrological analysis of the catchment. Hence, this research considered Port Harcourt city as a case study by utilizing 50 years rainfall data to develop rainfall Intensity-Duration-Frequency (IDF) curves that will be used for subsequent design of drainages and culverts within the city and its environs. The IDF curves were developed using Gumbel, Pearson type III and Log-Pearson type III distributions at return periods of 2, 5, 10, 25 and 50 years. However, the durations considered were $5,10,20,30,45,60,90,120,150,180,210,240,300,360$ and 420 minutes. Results showed that the IDF equations developed for the three frequency distributions highly correlate with the observed intensities since there goodness of fit $\left(R^{2}\right)$ ranges from $0.9766-0.9865$. Also, it was noted that there was no significant difference $(p<0.01)$ between the predicted rainfall intensities from all the IDF equations and the observed intensities. Notwithstanding, the IDF equation developed for Gumbel distribution was recommended to be given higher priority since it has the highest $R^{2}$ value.
\end{abstract}

Keywords: Gumbel, Pearson Type III, Log-Pearson Type III, Return-Period.

\section{INTRODUCTION}

Hydraulic structures such as bridges, culverts, drainages, dams, etc. are usually designed to serve for a certain period however most times, the structures failed to serve the intended purpose in certain years within the designed period due to excessive flood, runoff or high stream flow rates which all depends on rainfall. This has been recorded in different parts of the world especially in developing countries like Nigeria. For instance, the collapse of Tatabu bridge along Mokwa-Jebba road in Niger state of Nigeria in 2017 was attributed to increase in rainfall between 2015 and 2017 which directly increased the runoff and stream flow rate (Sule et al., 2018). Furthermore, a research conducted in Nigeria by (Ede et al., 2019) revealed that several bridges failed due to flood as could be seen in Table 1. 
Table 1: Some collapsed bridges in Nigeria caused by flood

\begin{tabular}{|c|c|c|c|}
\hline $\begin{array}{ll}\text { Name } & \text { of } \\
\text { Bridge } & \end{array}$ & State & Location & Year \\
\hline $\begin{array}{l}\text { Mararraban } \\
\text { Gassol Bembal } \\
\text { bridge }\end{array}$ & Taraba & $\begin{array}{l}\text { Wukari- } \\
\text { Jalingo road }\end{array}$ & 2018 \\
\hline $\begin{array}{l}\text { Gulbim Boka } \\
\text { bridge }\end{array}$ & Niger & Mariga & 2018 \\
\hline Eme bridge & Abia & $\begin{array}{l}\text { Amoji- } \\
\text { Imenyi, } \\
\text { Bende }\end{array}$ & 2017 \\
\hline $\begin{array}{l}\text { Bebuo Bomaji } \\
\text { bridge }\end{array}$ & $\begin{array}{l}\text { Cross } \\
\text { River }\end{array}$ & $\begin{array}{l}\text { Bebuo } \\
\text { Bomaji, Boki }\end{array}$ & 2017 \\
\hline $\begin{array}{l}\text { Idi-Iroko } \\
\text { bridge }\end{array}$ & Osun & Iwo & 2017 \\
\hline $\begin{array}{l}\text { Pandaragi } \\
\text { bridge }\end{array}$ & Kwara & Pandaragi & 2017 \\
\hline $\begin{array}{l}\text { Alagbado } \\
\text { bridge }\end{array}$ & Kwara & Ilorin East & 2017 \\
\hline Chibiri bridge & Plateau & $\begin{array}{l}\text { Langkaku, } \\
\text { Qua'an Pan }\end{array}$ & 2016 \\
\hline $\begin{array}{l}\text { Dubban Fulani } \\
\text { bridge }\end{array}$ & Gombe & $\begin{array}{l}\text { Dubban } \\
\text { fulani, Debba }\end{array}$ & 2015 \\
\hline $\begin{array}{l}\text { Odo pako } \\
\text { bridge }\end{array}$ & Ogun & Agbado & 2013 \\
\hline $\begin{array}{l}\text { Yar'randa } \\
\text { bridge }\end{array}$ & Katsina & $\begin{array}{l}\text { Yar'randa, } \\
\text { Charanchi }\end{array}$ & 2013 \\
\hline Imiringi bridge & Bayelsa & $\begin{array}{l}\text { Imiringi, } \\
\text { Ogbia }\end{array}$ & 2012 \\
\hline
\end{tabular}

Port Harcourt being the capital of Rivers state in South-Southern Nigeria have been experiencing annual flood in a significant scale (Echendu, 2021). Although urban flooding could be caused by several factors notwithstanding, lack of good surface drainage network system is a key factor. The procedure for constructing surface drainages requires geological survey of the site, hydrological analysis, hydraulic design as well as structural analysis of the drainage. However, in most developing countries, hydrological analysis that requires numerous data such as previous rainfalls for determination of rainfall intensity at given return period and duration; surface runoff as well as concentration time are not usually considered due to lack of experts and field data. In fact, most of the few rain gauges installed in certain cities in developing countries are not automated hence the amount or depth of rainfall is recorded manually by reading the values in the gauge at a regular interval within 24 hours (either 6-, 12- or 24-hours interval). In other words, getting field data for hydrological analysis is a big challenge facing most developing countries. This was earlier identified by Nwaogazie and Agiho (2019) who ascribed the issue of flooding in Port Harcourt to culvert inadequacy due to insufficient or lack of field data used in design. This affects the hydraulic design for optimal or most economical sections of drainages thus, causing surface drainage systems unable to contain future torrential rainfall, which would have been easily handled if reliable rainfall IDF models of the catchment are available. Notwithstanding, the rainfall IDF models for Port Harcourt has earlier been developed in two occasions by Nwaogazie and Duru (2002) as well as Nwaogazi and Sam (2019). However, the data employed in both occasions were insufficient as the former used 10 years $(1970-1979)$ rainfall data while the later utilized 16 years (1998 2013) rainfall data to develop the rainfall IDF models of the said area. Since rainfall IDF models are used in predicting rainfall intensities for return period as high as 50 years and even beyond, it requires a minimum of 30 years rainfall data for establishment of such models based on conventional standard. Hence, this research utilized 50 years $(1971-2020)$ rainfall data to establish rainfall IDF models for Port Harcourt so that it could be compared and used alongside with previous ones earlier developed.

\section{METHODS AND MATERIALS}

\section{Description of Study Area}

Port Harcourt is located in Southern Nigeria and it is the capital of Rivers State as well as the largest city in the state. It comprises of two Local Government Areas (LGAs) known as Port Harcourt city LGA and 
Obio-Akpor LGA (Figure 1), all enclosed in between Latitude $4^{0} 42^{\prime} 00^{\prime \prime}$ to $405^{\prime} 03^{\prime \prime}$ North and Longitude $6^{0} 53^{\prime} 11^{\prime \prime}$ to $708^{\prime} 49^{\prime \prime}$ East, with an approximate area of $369 \mathrm{~km}^{2}$. The peak daily rainfall in the study area for the past 50 years mostly occurs between the months of June to October.

The first meteorological station in the study area was first established in 1965 at the Airforce Base (Latitude $4^{0}$ 50' 53.89" North; Longitude $7^{0} 1^{\prime} 17.87^{\prime \prime}$ East) along
Port Harcourt - Aba road. However, the Nigerian civil war that lasted for 30months (July, 1967 to January, 1970) led to the missing of rainfall data during this period since the rainfall depths were recorded manually from the rain gauge. Notwithstanding, the station commenced operations again between 1970 to 1979 but moved to the Port Harcourt International Airport Omagwa (Latitude $5^{0} 0^{\prime}$ 54.58"

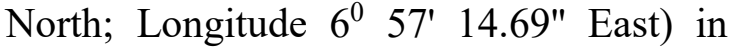
1980 and it has remained there since then.

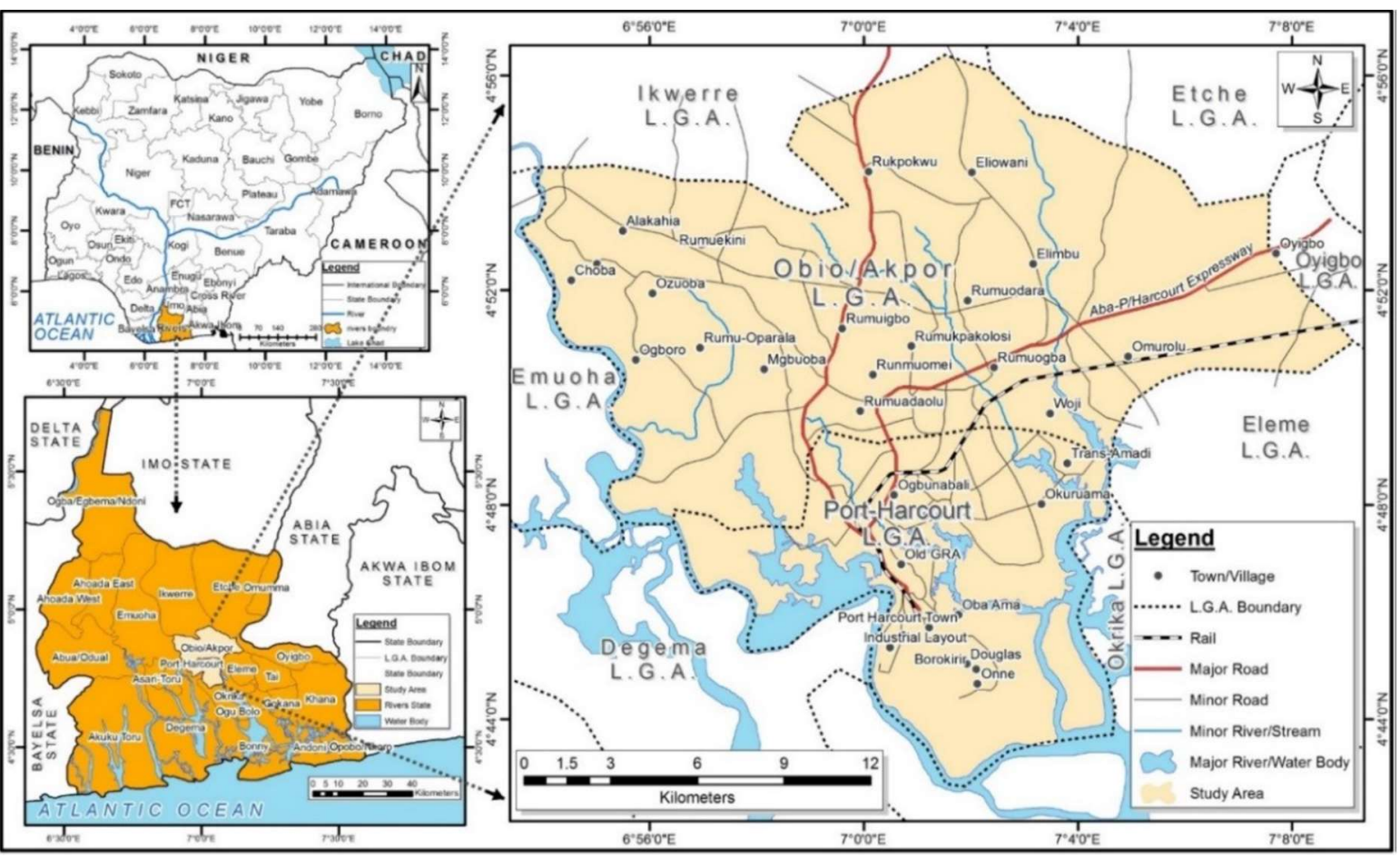

Figure 1: Map of study area

\section{Data Collection and Analysis}

Beginning from the year 1971 to 2020 (50 years), the highest or maximum daily rainfall depth $(\mathrm{mm})$ for each year in Port Harcourt were obtained from the headquarters of Nigerian Meteorological Agency (NIMET), Abuja. Since the daily (24hours) rainfall depths were manually recorded, the maximum rainfall depths corresponding to shorter durations $(5,10$, $20,30,45,60,90,120,150,180,210,240$, 300,360 and 420 minutes) for each year were determined by employing the empirical model developed by the Indian Meteorological Department (IMD) shown in Equation (1) as follows.

$$
P_{t}=P_{24}\left(\frac{t}{24}\right)^{1 / 3}
$$

where $P_{t}$ is the required precipitation depth in $\mathrm{mm}$ for t-hours, $P_{24}$ is the annual maximum daily (24-hours) rainfall depth in $\mathrm{mm}$ and $t$ is the duration in hours for the required precipitation depth.

The rainfall intensities (I) in $\mathrm{mm} /$ hour for the different durations were obtained by dividing the rainfall depths in $\mathrm{mm}$ by their corresponding durations in hours. The intensities (I) obtained for the various durations were ranked in descending order ( $\mathrm{m}=1$ for highest intensity) thereafter, the frequencies (return periods) of the various 
storms were calculated using the Weibull's method as shown in Equation (2).

$T=\frac{n+1}{m}$

where $T$ is the frequency or return period, $n$ is the number of years of recorded data $(50)$ and $m$ is the rank. The return period for urban drainage and culvert designs within the region, (Nigeria) is usually 25 years but in order to develop IDF equations for the catchment, other return periods apart from 25 , present in standard frequency or return period tables were considered. Hence, this research considered return periods $2,5,10$, 25 and 50 years.

The intensities for each return period were plotted against their respective durations on a linear graph. Gumbel, Pearson type III and Log-Pearson type III distributions, which are most commonly used for IDF curves were developed for the catchment by means of the general hydrologic frequency distribution model given in Equation (3).

$$
X_{T}=\bar{X}+K_{T} \sigma
$$

where $X_{T}$ is the rainfall intensity for a return period $T, \bar{X}$ is the arithmetic mean of rainfall intensity for a given storm duration, $\sigma$ is the standard deviation of rainfall intensity for a given storm duration while $K_{T}$ is the frequency factor which is a function of return period $T$. The frequency factor $K_{T}$ for Gumbel's distribution was determined by means of Equation (4) as follows:

$$
K_{T}=-\frac{\sqrt{6}}{\pi}\left[0.5772+\ln \left(\ln \frac{T}{T-1}\right)\right]
$$

where $T$ is the return period.

The Pearson type III distribution is usually suitable for skewed data hence the $K_{T}$ factor also depends on the coefficient of skewness which was determined by means of Equation (5).

$$
C_{s}=\frac{n \sum_{i=1}^{n}\left(X_{i=1}-\bar{X}\right)^{3}}{(n-1)(n-2) \sigma^{3}}
$$

where $C_{s}$ is coefficient of skewness, $n$ is the number of years of recorded data (sample size $=50), X_{i}$ is the individual or yearly rainfall intensity for a given duration, $\bar{X}$ is the arithmetic mean of rainfall intensity for a given duration, $\sigma$ is the standard deviation of rainfall intensity for a given duration. Hence, the frequency factor $K_{T}$ for Pearson type III distribution for a given return period was obtained from standard table using the determined coefficient of skewness.

The frequency factor $K_{T}$ for Log-Pearson type III distribution was obtained in similar way just as in the case of Pearson type III distribution however, the rainfall intensities were logarithmically transformed to base 10. In other words, the arithmetic mean and standard deviation of the rainfall intensities were calculated based on the logarithmically transformed data, and were used to determine the skewness coefficient. Thereafter, the frequency factor $K_{T}$ for a given return period was obtained from standard table using the skewness coefficient already determined. Hence, the calculated logarithmically transformed mean, standard deviation and frequency factor $K_{T}$ of each duration for a given return period, were substituted into Equation (3) to obtain the corresponding log-transformed rainfall intensities. Thus, the antilog of the solutions obtained in Equation (3) i.e. antilog of log-transformed rainfall intensities, gives the actual rainfall intensities of the various rainfall durations and return periods.

\subsection{Derivation of IDF Equations}

The general equation relating the dependent variable (rainfall intensity) and the independent variables (rainfall duration and return period or frequency) governing each frequency distribution (Gumbel, Pearson type III and Log-Pearson type III) curve were determined via the commonly used Sherman's model shown in Equation (6). 
$i=\frac{c T^{m}}{t^{e}}$

where $i$ is the rainfall intensity in $\mathrm{mm} / \mathrm{hr}, T$ is the frequency or return period in years, $t$ is the rainfall duration in minutes, while $c$, $m$ and $e$ are constants depending on the region or catchment. The procedure used in determining these regional constants $(c, m$ and $e$ ) are as described as follows:

Equation (6) was linearized logarithmically as shown in Equation (7).

$\log i=-e \log t+\log K$

where $K$ is expressed in Equation (8);

$K=c T^{m}$

Equation (7) was applied on the data for each frequency distribution (Gumbel, Pearson type III and Log-Pearson type III) at a given return period $T$, by plotting values of $\log i$ (on the y-axis) against $\log t$ (on the $\mathrm{x}$-axis) using a linear graph. The slope or gradient of the graph was taken as the constant $e$ for the return period considered. The arithmetic mean of the various values of $e$ (slopes) resulting from each return period were calculated, and taken as the regional constant $e$ for Equation (7). Also, the y-intercepts of the graphs plotted were taken as the values of $\log K$ (where $K=c T^{m}$ ) for their corresponding return period $T$. In order to determine the regional constants $c$ and $m$, Equation (8) was also linearized as shown in Equation (9).

$\log K=m \log T+\log c$
Hence, Equation (9) was applied on the data for the various frequency distributions by plotting the various values of $\log K$ (already determined as $y$-intercepts of the graphs of Equation 7) against the $\log$ of their corresponding return periods $T$ on a linear graph. Thus, the slope of the graph obtained represent the constant $m$ while the $y$ intercept was taken as $\log c$. Hence the actual value of constant $c$ was determined by obtaining the antilog of the y-intercept of Equation (9) graph.

The constants $c, m$ and $e$ obtained for Gumbel, Pearson type III and Log-Pearson type III distribution functions were substituted into the Sherman's IDF model presented in Equation (6), as the general IDF equation for the catchment with respect to the considered frequency distribution functions.

In order to decide the best IDF equation, a correlation analysis was carried out between the original rainfall intensities (observed data) and the rainfall intensities obtained through the IDF equations (predicted data). The one with the highest value of determination coefficient $\left(\mathrm{R}^{2}\right)$ was considered as the IDF equation that best suits the catchment.

\section{RESULTS AND DISCUSSION}

\section{Results}

The original rainfall intensities for the various durations are ranked as shown in Table 2.

\section{Table 2: Ranked computed rainfall intensities $(\mathrm{mm} / \mathrm{h})$ for short durations}

\begin{tabular}{cccccccccccccccc}
\hline $\begin{array}{c}\text { Rank } \\
\boldsymbol{m}\end{array}$ & $\begin{array}{c}\mathbf{5} \\
\text { min. }\end{array}$ & $\begin{array}{c}\mathbf{1 0} \\
\text { min. }\end{array}$ & $\begin{array}{c}\mathbf{2 0} \\
\text { min. }\end{array}$ & $\begin{array}{c}\mathbf{3 0} \\
\text { min. }\end{array}$ & $\begin{array}{c}\mathbf{4 5} \\
\text { min. }\end{array}$ & $\begin{array}{c}\mathbf{6 0} \\
\text { min. }\end{array}$ & $\begin{array}{c}\mathbf{9 0} \\
\text { min. }\end{array}$ & $\begin{array}{c}\mathbf{1 2 0} \\
\text { min. }\end{array}$ & $\begin{array}{c}\mathbf{1 5 0} \\
\text { min. }\end{array}$ & $\begin{array}{c}\mathbf{1 8 0} \\
\text { min. }\end{array}$ & $\begin{array}{c}\mathbf{2 1 0} \\
\text { min. }\end{array}$ & $\begin{array}{c}\mathbf{2 4 0} \\
\text { min. }\end{array}$ & $\begin{array}{c}\mathbf{3 0 0} \\
\text { min. }\end{array}$ & $\begin{array}{c}\mathbf{3 6 0} \\
\text { min. }\end{array}$ & $\begin{array}{c}\mathbf{4 2 0} \\
\text { min. }\end{array}$ \\
\hline $\mathbf{1}^{*}$ & 337.8 & 211.7 & 133.7 & 101.9 & 77.8 & 64.3 & 49.0 & 40.5 & 34.9 & 30.9 & 27.9 & 25.5 & 22.0 & 19.5 & 17.6 \\
$\mathbf{2}^{*}$ & 316.1 & 198.1 & 125.1 & 95.4 & 72.8 & 60.1 & 45.9 & 37.9 & 32.6 & 28.9 & 26.1 & 23.9 & 20.6 & 18.2 & 16.4 \\
3 & 297.0 & 186.1 & 117.5 & 89.6 & 68.4 & 56.5 & 43.1 & 35.6 & 30.7 & 27.2 & 24.5 & 22.4 & 19.3 & 17.1 & 15.4 \\
4 & 259.4 & 162.6 & 102.7 & 78.3 & 59.8 & 49.4 & 37.7 & 31.1 & 26.8 & 23.7 & 21.4 & 19.6 & 16.9 & 14.9 & 13.5 \\
$\mathbf{5}^{*}$ & 258.0 & 161.7 & 102.1 & 77.8 & 59.4 & 49.1 & 37.4 & 30.9 & 26.6 & 23.6 & 21.3 & 19.5 & 16.8 & 14.9 & 13.4 \\
6 & 243.9 & 152.9 & 96.5 & 73.6 & 56.2 & 46.4 & 35.4 & 29.2 & 25.2 & 22.3 & 20.1 & 18.4 & 15.9 & 14.0 & 12.7 \\
7 & 243.2 & 152.4 & 96.2 & 73.4 & 56.0 & 46.3 & 35.3 & 29.1 & 25.1 & 22.2 & 20.1 & 18.4 & 15.8 & 14.0 & 12.6 \\
8 & 242.1 & 151.7 & 95.8 & 73.1 & 55.8 & 46.1 & 35.1 & 29.0 & 25.0 & 22.1 & 20.0 & 18.3 & 15.7 & 13.9 & 12.6 \\
9 & 240.3 & 150.6 & 95.1 & 72.5 & 55.4 & 45.7 & 34.9 & 28.8 & 24.8 & 22.0 & 19.8 & 18.1 & 15.6 & 13.8 & 12.5
\end{tabular}




\begin{tabular}{|c|c|c|c|c|c|c|c|c|c|c|c|c|c|c|c|}
\hline $10^{*}$ & 236.3 & 148.1 & 93.5 & 71.3 & 54.4 & 44.9 & 34.3 & 28.3 & 24.4 & 21.6 & 19.5 & 17.8 & 15.4 & 13.6 & 12.3 \\
\hline 11 & 234.3 & 146.8 & 92.7 & 70.7 & 54.0 & 44.6 & 34.0 & 28.1 & 24.2 & 21.4 & 19.3 & 17.7 & 15.2 & 13.5 & 12.2 \\
\hline 12 & 234.1 & 146.7 & 92.6 & 70.6 & 53.9 & 44.5 & 34.0 & 28.0 & 24.2 & 21.4 & 19.3 & 17.7 & 15.2 & 13.5 & 12.2 \\
\hline 13 & 231.0 & 144.7 & 91.4 & 69.7 & 53.2 & 43.9 & 33.5 & 27.7 & 23.9 & 21.1 & 19.1 & 17.4 & 15.0 & 13.3 & 12.0 \\
\hline 14 & 229.5 & 143.8 & 90.8 & 69.3 & 52.9 & 43.7 & 33.3 & 27.5 & 23.7 & 21.0 & 18.9 & 17.3 & 14.9 & 13.2 & 11.9 \\
\hline 15 & 224.0 & 140.4 & 88.7 & 67.6 & 51.6 & 42.6 & 32.5 & 26.8 & 23.1 & 20.5 & 18.5 & 16.9 & 14.6 & 12.9 & 11.6 \\
\hline 16 & 217.7 & 136.4 & 86.1 & 65.7 & 50.2 & 41.4 & 31.6 & 26.1 & 22.5 & 19.9 & 18.0 & 16.4 & 14.2 & 12.5 & 11.3 \\
\hline 17 & 217.7 & 136.4 & 86.1 & 65.7 & 50.2 & 41.4 & 31.6 & 26.1 & 22.5 & 19.9 & 18.0 & 16.4 & 14.2 & 12.5 & 11.3 \\
\hline 18 & 215.3 & 134.9 & 85.2 & 65.0 & 49.6 & 41.0 & 31.2 & 25.8 & 22.2 & 19.7 & 17.8 & 16.3 & 14.0 & 12.4 & 11.2 \\
\hline 19 & 210.2 & 131.7 & 83.2 & 63.4 & 48.4 & 40.0 & 30.5 & 25.2 & 21.7 & 19.2 & 17.3 & 15.9 & 13.7 & 12.1 & 10.9 \\
\hline 20 & 205.1 & 128.5 & 81.2 & 61.9 & 47.3 & 39.0 & 29.8 & 24.6 & 21.2 & 18.8 & 16.9 & 15.5 & 13.3 & 11.8 & 10.7 \\
\hline 21 & 202.9 & 127.2 & 80.3 & 61.2 & 46.7 & 38.6 & 29.4 & 24.3 & 21.0 & 18.6 & 16.7 & 15.3 & 13.2 & 11.7 & 10.5 \\
\hline 22 & 197.3 & 123.6 & 78.1 & 59.5 & 45.4 & 37.5 & 28.6 & 23.6 & 20.4 & 18.0 & 16.3 & 14.9 & 12.8 & 11.4 & 10.3 \\
\hline 23 & 190.1 & 119.2 & 75.3 & 57.4 & 43.8 & 36.2 & 27.6 & 22.8 & 19.6 & 17.4 & 15.7 & 14.4 & 12.4 & 11.0 & 9.9 \\
\hline 24 & 189.2 & 118.6 & 74.9 & 57.1 & 43.6 & 36.0 & 27.5 & 22.7 & 19.5 & 17.3 & 15.6 & 14.3 & 12.3 & 10.9 & 9.8 \\
\hline 25 & 188.7 & 118.2 & 74.7 & 56.9 & 43.5 & 35.9 & 27.4 & 22.6 & 19.5 & 17.3 & 15.6 & 14.2 & 12.3 & 10.9 & 9.8 \\
\hline $26^{*}$ & 188.0 & 117.8 & 74.4 & 56.7 & 43.3 & 35.8 & 27.3 & 22.5 & 19.4 & 17.2 & 15.5 & 14.2 & 12.2 & 10.8 & 9.8 \\
\hline 27 & 183.2 & 114.8 & 72.5 & 55.3 & 42.2 & 34.9 & 26.6 & 21.9 & 18.9 & 16.8 & 15.1 & 13.8 & 11.9 & 10.6 & 9.5 \\
\hline 28 & 180.7 & 113.2 & 71.5 & 54.5 & 41.6 & 34.4 & 26.2 & 21.6 & 18.7 & 16.5 & 14.9 & 13.6 & 11.7 & 10.4 & 9.4 \\
\hline 29 & 179.6 & 112.5 & 71.1 & 54.2 & 41.4 & 34.2 & 26.1 & 21.5 & 18.5 & 16.4 & 14.8 & 13.6 & 11.7 & 10.3 & 9.3 \\
\hline 30 & 178.5 & 111.8 & 70.6 & 53.9 & 41.1 & 34.0 & 25.9 & 21.4 & 18.4 & 16.3 & 14.7 & 13.5 & 11.6 & 10.3 & 9.3 \\
\hline 31 & 178.3 & 111.7 & 70.6 & 53.8 & 41.1 & 33.9 & 25.9 & 21.4 & 18.4 & 16.3 & 14.7 & 13.5 & 11.6 & 10.3 & 9.3 \\
\hline 32 & 177.6 & 111.3 & 70.3 & 53.6 & 40.9 & 33.8 & 25.8 & 21.3 & 18.3 & 16.2 & 14.6 & 13.4 & 11.5 & 10.2 & 9.2 \\
\hline 33 & 175.6 & 110.0 & 69.5 & 53.0 & 40.4 & 33.4 & 25.5 & 21.0 & 18.1 & 16.1 & 14.5 & 13.3 & 11.4 & 10.1 & 9.1 \\
\hline 34 & 171.0 & 107.2 & 67.7 & 51.6 & 39.4 & 32.5 & 24.8 & 20.5 & 17.7 & 15.6 & 14.1 & 12.9 & 11.1 & 9.8 & 8.9 \\
\hline 35 & 170.6 & 106.9 & 67.5 & 51.5 & 39.3 & 32.5 & 24.8 & 20.4 & 17.6 & 15.6 & 14.1 & 12.9 & 11.1 & 9.8 & 8.9 \\
\hline 36 & 169.9 & 106.5 & 67.2 & 51.3 & 39.1 & 32.3 & 24.7 & 20.4 & 17.5 & 15.5 & 14.0 & 12.8 & 11.1 & 9.8 & 8.8 \\
\hline 37 & 169.4 & 106.1 & 67.0 & 51.1 & 39.0 & 32.2 & 24.6 & 20.3 & 17.5 & 15.5 & 14.0 & 12.8 & 11.0 & 9.8 & 8.8 \\
\hline 38 & 157.0 & 98.4 & 62.1 & 47.4 & 36.2 & 29.9 & 22.8 & 18.8 & 16.2 & 14.4 & 12.9 & 11.8 & 10.2 & 9.0 & 8.2 \\
\hline 39 & 151.9 & 95.2 & 60.1 & 45.8 & 35.0 & 28.9 & 22.0 & 18.2 & 15.7 & 13.9 & 12.5 & 11.5 & 9.9 & 8.7 & 7.9 \\
\hline 40 & 147.5 & 92.4 & 58.4 & 44.5 & 34.0 & 28.1 & 21.4 & 17.7 & 15.2 & 13.5 & 12.2 & 11.1 & 9.6 & 8.5 & 7.7 \\
\hline 41 & 146.8 & 92.0 & 58.1 & 44.3 & 33.8 & 27.9 & 21.3 & 17.6 & 15.2 & 13.4 & 12.1 & 11.1 & 9.5 & 8.5 & 7.6 \\
\hline 42 & 146.4 & 91.7 & 57.9 & 44.2 & 33.7 & 27.8 & 21.2 & 17.5 & 15.1 & 13.4 & 12.1 & 11.0 & 9.5 & 8.4 & 7.6 \\
\hline 43 & 146.4 & 91.7 & 57.9 & 44.2 & 33.7 & 27.8 & 21.2 & 17.5 & 15.1 & 13.4 & 12.1 & 11.0 & 9.5 & 8.4 & 7.6 \\
\hline 44 & 140.0 & 87.7 & 55.4 & 42.2 & 32.3 & 26.6 & 20.3 & 16.8 & 14.5 & 12.8 & 11.5 & 10.6 & 9.1 & 8.1 & 7.3 \\
\hline 45 & 136.4 & 85.5 & 54.0 & 41.1 & 31.4 & 25.9 & 19.8 & 16.3 & 14.1 & 12.5 & 11.2 & 10.3 & 8.9 & 7.9 & 7.1 \\
\hline 46 & 132.0 & 82.7 & 52.2 & 39.8 & 30.4 & 25.1 & 19.2 & 15.8 & 13.6 & 12.1 & 10.9 & 10.0 & 8.6 & 7.6 & 6.9 \\
\hline 47 & 129.4 & 81.1 & 51.2 & 39.1 & 29.8 & 24.6 & 18.8 & 15.5 & 13.4 & 11.8 & 10.7 & 9.8 & 8.4 & 7.5 & 6.7 \\
\hline 48 & 127.6 & 80.0 & 50.5 & 38.5 & 29.4 & 24.3 & 18.5 & 15.3 & 13.2 & 11.7 & 10.5 & 9.6 & 8.3 & 7.3 & 6.6 \\
\hline 49 & 125.4 & 78.6 & 49.6 & 37.8 & 28.9 & 23.9 & 18.2 & 15.0 & 13.0 & 11.5 & 10.3 & 9.5 & 8.2 & 7.2 & 6.5 \\
\hline 50 & 122.3 & 76.7 & 48.4 & 36.9 & 28.2 & 23.3 & 17.8 & 14.7 & 12.6 & 11.2 & 10.1 & 9.2 & 8.0 & 7.0 & 6.4 \\
\hline $\bar{X}$ & 195.8 & 122.7 & 77.5 & 59.1 & 45.1 & 37.3 & 28.4 & 23.5 & 20.2 & 17.9 & 16.2 & 14.8 & 12.7 & 11.3 & 10.2 \\
\hline$\sigma$ & 49.3 & 30.9 & 19.5 & 14.9 & 11.3 & 9.4 & 7.1 & 5.9 & 5.1 & 4.5 & 4.1 & 3.7 & 3.2 & 2.8 & 2.6 \\
\hline$C_{s}$ & 0.735 & 0.735 & 0.735 & 0.728 & 0.750 & 0.713 & 0.760 & 0.714 & 0.742 & 0.740 & 0.682 & 0.729 & 0.773 & 0.740 & 0.676 \\
\hline
\end{tabular}

\section{Gumbel's Distribution}

The frequency factor $K_{T}$ for Gumbel's distribution for the various return periods 2 , $5,10,25$ and 50 were obtained from Equation (4) as $-0.1643,0.7194,1.3044$, 2.0436 and 2.5919 respectively. The mean $(\bar{X})$ and standard deviation $(\sigma)$ values corresponding to various storm durations in Table 2, together with the computed $K_{T}$ values were substituted in Equation (3) to generate the corresponding rainfall intensities for Gumbel's distribution, shown in Table 3 and consequently Figure 2. 
Table 3: Gumbel's distribution rainfall intensity $(\mathrm{mm} / \mathrm{hr})$ for considered return periods

\begin{tabular}{|c|c|c|c|c|c|c|c|c|c|c|c|c|c|c|c|c|}
\hline $\begin{array}{c}\text { Rank } \\
m\end{array}$ & $\begin{array}{c}5 \\
\text { min. }\end{array}$ & $\begin{array}{c}10 \\
\text { min. }\end{array}$ & $\begin{array}{c}20 \\
\text { min. }\end{array}$ & $\begin{array}{c}30 \\
\text { min. }\end{array}$ & $\begin{array}{c}45 \\
\text { min. }\end{array}$ & $\begin{array}{c}60 \\
\text { min. }\end{array}$ & $\begin{array}{c}90 \\
\text { min. }\end{array}$ & $\begin{array}{l}120 \\
\min \end{array}$ & $\begin{array}{l}150 \\
\text { min. }\end{array}$ & $\begin{array}{l}180 \\
\text { min. }\end{array}$ & $\begin{array}{l}210 \\
\text { min. }\end{array}$ & $\begin{array}{l}240 \\
\text { min. }\end{array}$ & $\begin{array}{l}300 \\
\text { min. }\end{array}$ & $\begin{array}{l}360 \\
\text { min. }\end{array}$ & $\begin{array}{l}420 \\
\text { min. }\end{array}$ & $T=\frac{n+1}{m}$ \\
\hline 26 & 187.8 & 117.7 & 74.3 & 56.7 & 43.3 & 35.7 & 27.3 & 22.5 & 19.4 & 17.2 & 15.5 & 14.2 & 12.2 & 10.8 & 9.8 & 2 \\
\hline 10 & 231.3 & 144.9 & 91.5 & 69.8 & 53.3 & 44.0 & 33.6 & 27.7 & 23.9 & 21.1 & 19.1 & 17.5 & 15.0 & 13.3 & 12.0 & 5 \\
\hline 5 & 260.1 & 163.0 & 102.9 & 78.5 & 59.9 & 49.5 & 37.8 & 31.2 & 26.9 & 23.8 & 21.5 & 19.6 & 16.9 & 15.0 & 13.5 & 10 \\
\hline 2 & 296.5 & 185.8 & 117.3 & 89.5 & 68.3 & 56.4 & 43.0 & 35.5 & 30.6 & 27.1 & 24.5 & 22.4 & 19.3 & 17.1 & 15.4 & 25 \\
\hline 1 & 323.6 & 202.8 & 128.0 & 97.7 & 74.4 & 61.7 & 46.8 & 38.8 & 33.4 & 29.6 & 26.8 & 24.4 & 21.0 & 18.6 & 16.9 & 50 \\
\hline
\end{tabular}

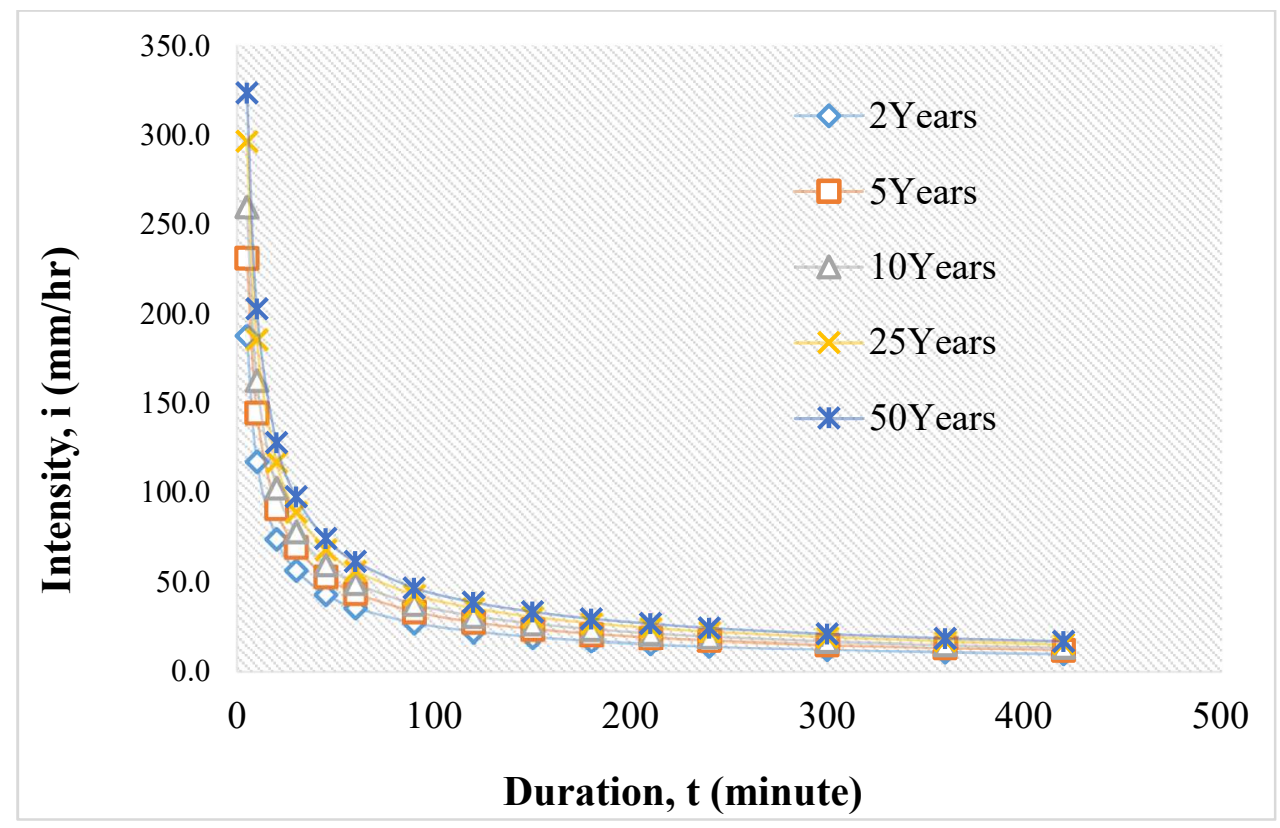

Figure 2: IDF curves for Gumbel's distribution

\subsubsection{Pearson type III distribution}

The skewness coefficients $C_{s}$ of the various durations shown in Table 2 lies between 0.6 and 0.8 hence, the frequency factor $\left(K_{T}\right)$ for each return period corresponding to the computed skewness coefficient were interpolated between 0.6 and 0.8 from standard Pearson type (III) table. The obtained interpolated $K_{T}$ values alongside the mean $(\bar{X})$ and standard deviation $(\sigma)$ values corresponding to the various durations in Table 2 were substituted into Equation (3) to generate the rainfall intensity values presented in Table 4 . The intensities values in Table 4 were used in producing the IDF curves in Figure 3.

Table 4: Pearson type (III) rainfall intensities ( $\mathrm{mm} / \mathrm{hr}$ ) for considered return periods

\begin{tabular}{|c|c|c|c|c|c|c|c|c|c|c|c|c|c|c|c|c|}
\hline $\begin{array}{c}\text { Rank } \\
m\end{array}$ & $\begin{array}{c}5 \\
\text { min. }\end{array}$ & $\begin{array}{c}10 \\
\text { min. }\end{array}$ & $\begin{array}{c}20 \\
\text { min. }\end{array}$ & $\begin{array}{c}30 \\
\text { min. }\end{array}$ & $\begin{array}{c}45 \\
\text { min. }\end{array}$ & $\begin{array}{c}60 \\
\text { min. }\end{array}$ & $\begin{array}{c}90 \\
\text { min. }\end{array}$ & $\begin{array}{l}120 \\
\text { min }\end{array}$ & $\begin{array}{l}150 \\
\text { min. }\end{array}$ & $\begin{array}{l}180 \\
\text { min. }\end{array}$ & $\begin{array}{l}210 \\
\text { min. }\end{array}$ & $\begin{array}{l}240 \\
\text { min. }\end{array}$ & $\begin{array}{l}300 \\
\text { min. }\end{array}$ & $\begin{array}{l}360 \\
\text { min. }\end{array}$ & $\begin{array}{l}420 \\
\text { min. }\end{array}$ & $T=\frac{n+1}{m}$ \\
\hline 26 & 189.9 & 119.0 & 75.1 & 57.3 & 43.7 & 36.2 & 27.5 & 22.8 & 19.6 & 17.4 & 15.7 & 14.3 & 12.3 & 10.9 & 9.9 & 2 \\
\hline 10 & 234.6 & 147.0 & 92.8 & 70.8 & 54.0 & 44.6 & 34.0 & 28.1 & 24.2 & 21.4 & 19.4 & 17.7 & 15.2 & 13.5 & 12.2 & 5 \\
\hline 5 & 261.5 & 163.9 & 103.5 & 78.9 & 60.3 & 49.7 & 38.0 & 31.3 & 27.0 & 23.9 & 21.6 & 19.7 & 17.0 & 15.1 & 13.6 & 10 \\
\hline 2 & 293.2 & 183.7 & 116.0 & 88.4 & 67.6 & 55.7 & 42.6 & 35.1 & 30.3 & 26.8 & 24.1 & 22.1 & 19.1 & 16.9 & 15.2 & 25 \\
\hline 1 & 315.2 & 197.5 & 124.7 & 95.1 & 72.7 & 59.9 & 45.8 & 37.7 & 32.6 & 28.8 & 25.9 & 23.8 & 20.6 & 18.2 & 16.3 & 50 \\
\hline
\end{tabular}




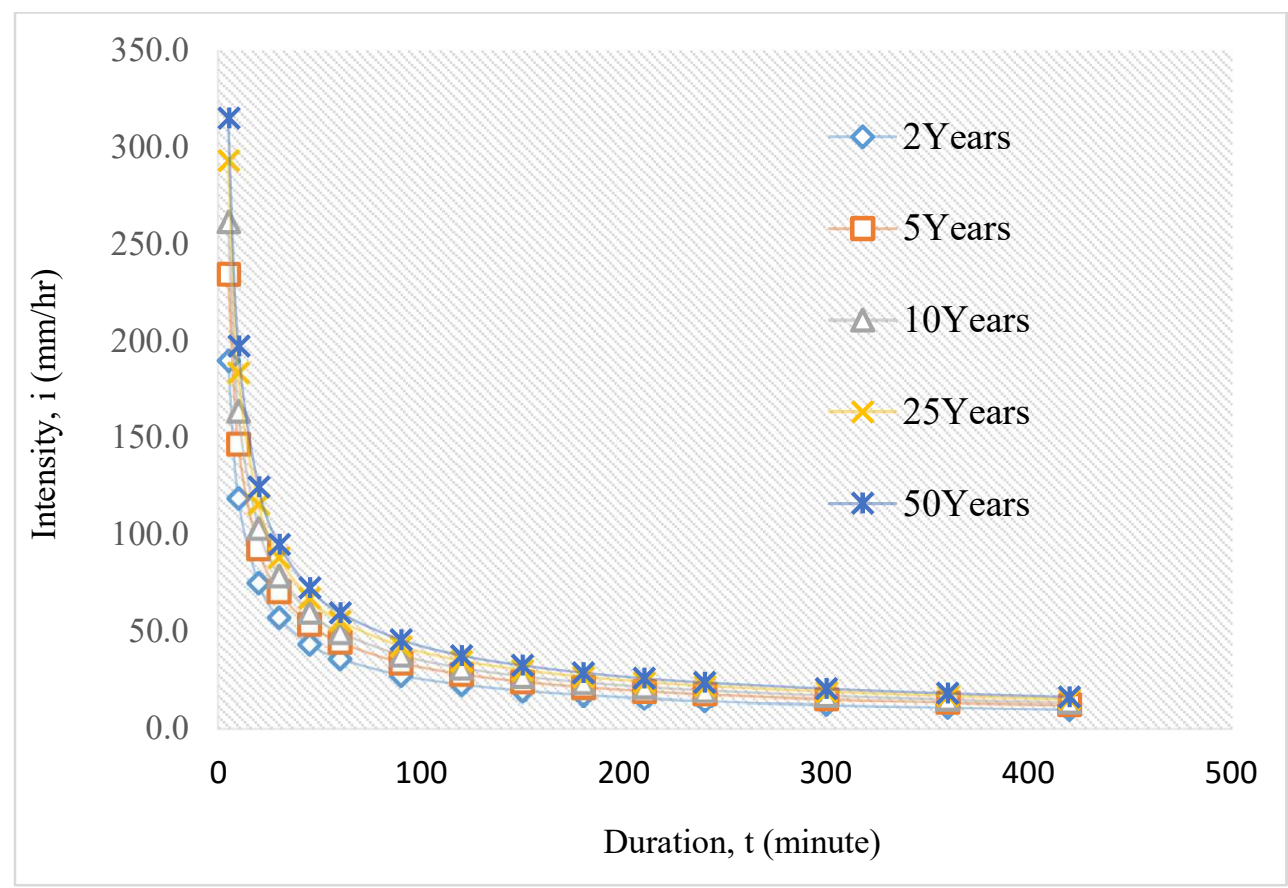

Figure 3: IDF curves for Pearson type (III) distribution

\section{Log-Pearson type (III) distribution}

The intensity values shown in Table 2 were logarithmically transformed to obtain logtransformed mean, standard deviation and skewness coefficient for each of the duration. The corresponding transformed frequency factors $\left(K_{T}\right)$ were obtained in standard table by interpolation just as in the case of Pearson type (III). The obtained log- transformed mean $(\bar{X})$, standard deviation $(\sigma)$ and frequency factor $\left(K_{T}\right)$ for the various durations and considered return periods were substituted into Equation (3) to yield log-transform intensity values. The actual intensity values, which is the antilog of the log-transformed intensities, are shown in Table 5 while the corresponding IDF curves are shown in Figure 4.

Table 5: Log-Pearson type (III) rainfall intensities $(\mathrm{mm} / \mathrm{hr}$ ) for considered return periods

\begin{tabular}{|c|c|c|c|c|c|c|c|c|c|c|c|c|c|c|c|c|}
\hline $\begin{array}{c}\text { Rank } \\
m\end{array}$ & $\begin{array}{c}5 \\
\text { min. }\end{array}$ & $\begin{array}{c}10 \\
\text { min. }\end{array}$ & $\begin{array}{c}20 \\
\text { min. }\end{array}$ & $\begin{array}{c}30 \\
\text { min. }\end{array}$ & $\begin{array}{c}45 \\
\text { min. }\end{array}$ & $\begin{array}{c}60 \\
\text { min. }\end{array}$ & $\begin{array}{c}90 \\
\text { min. }\end{array}$ & $\begin{array}{l}120 \\
\text { min }\end{array}$ & $\begin{array}{l}150 \\
\text { min. }\end{array}$ & $\begin{array}{l}180 \\
\text { min. }\end{array}$ & $\begin{array}{l}210 \\
\text { min. }\end{array}$ & $\begin{array}{l}240 \\
\text { min. }\end{array}$ & $\begin{array}{l}300 \\
\text { min. }\end{array}$ & $\begin{array}{l}360 \\
\text { min. }\end{array}$ & $\begin{array}{l}420 \\
\text { min. }\end{array}$ & $T=\frac{n+1}{m}$ \\
\hline 26 & 189.0 & 118.4 & 74.8 & 57.1 & 43.5 & 35.9 & 27.4 & 22.6 & 19.5 & 17.3 & 15.6 & 14.3 & 12.3 & 10.9 & 9.8 & 2 \\
\hline 10 & 233.3 & 146.2 & 92.3 & 70.4 & 53.8 & 44.4 & 33.9 & 27.9 & 24.1 & 21.3 & 19.2 & 17.6 & 15.2 & 13.4 & 12.1 & 5 \\
\hline 5 & 261.5 & 163.9 & 103.5 & 78.9 & 60.3 & 49.8 & 37.9 & 31.3 & 27.0 & 23.9 & 21.6 & 19.7 & 17.0 & 15.1 & 13.6 & 10 \\
\hline 2 & 295.8 & 185.3 & 117.1 & 89.2 & 68.2 & 56.3 & 42.9 & 35.5 & 30.5 & 27.0 & 24.4 & 22.3 & 19.2 & 17.0 & 15.4 & 25 \\
\hline 1 & 320.7 & 201.0 & 127.1 & 96.6 & 74.0 & 61.1 & 46.5 & 38.5 & 33.1 & 29.3 & 26.5 & 24.2 & 20.9 & 18.5 & 16.6 & 50 \\
\hline
\end{tabular}




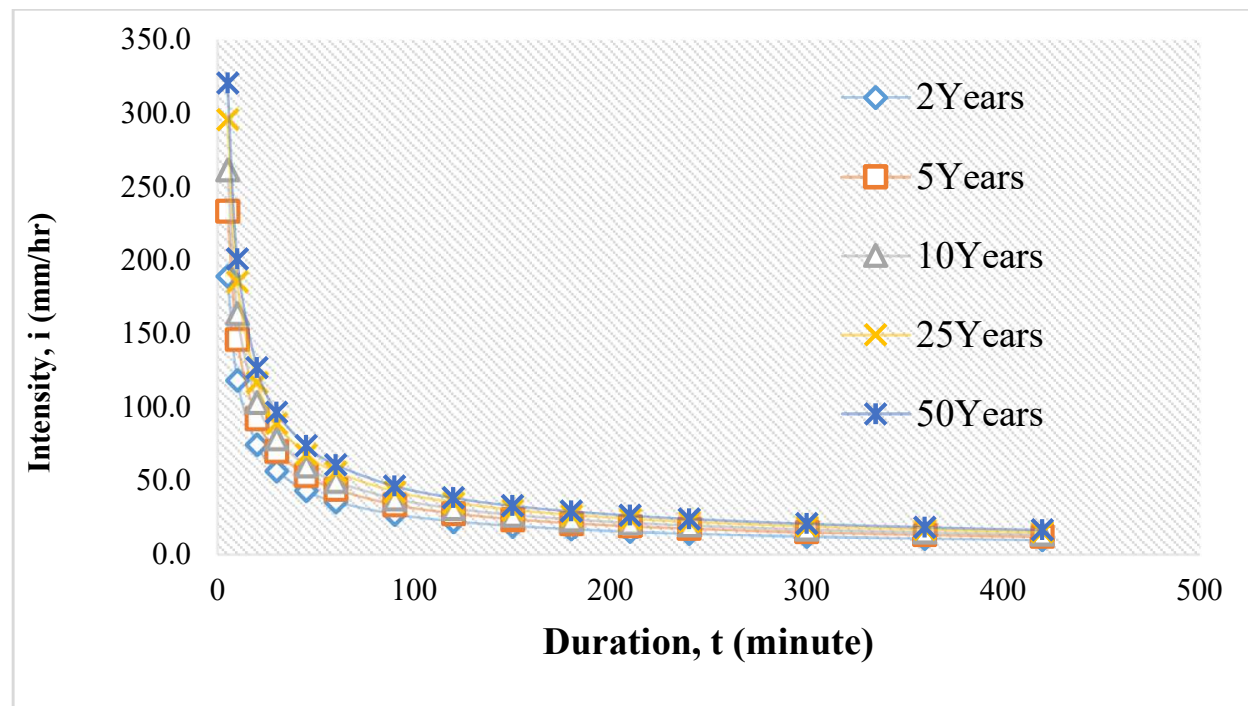

Figure 4: IDF curves for Log-Pearson type (III) distribution

\section{IDF equations}

The regional constant $e$ in Sherman's model was determined for Gumbel's distribution by plotting the log of rainfall intensity (log i) against the $\log$ of their corresponding duration $(\log t)$ for each return period as shown in Figure 5. The regression lines associated with the various plots shown in
Figure 5 were compared with Equation (7) and the average value of the constant $e$ was obtained (0.66686). The associated $y$ intercepts of the various plots in Figure 5, which represent $\log K$ (based on Equation 7) were plotted against the log of their corresponding return period $(\log T)$ as shown in Figure 6.

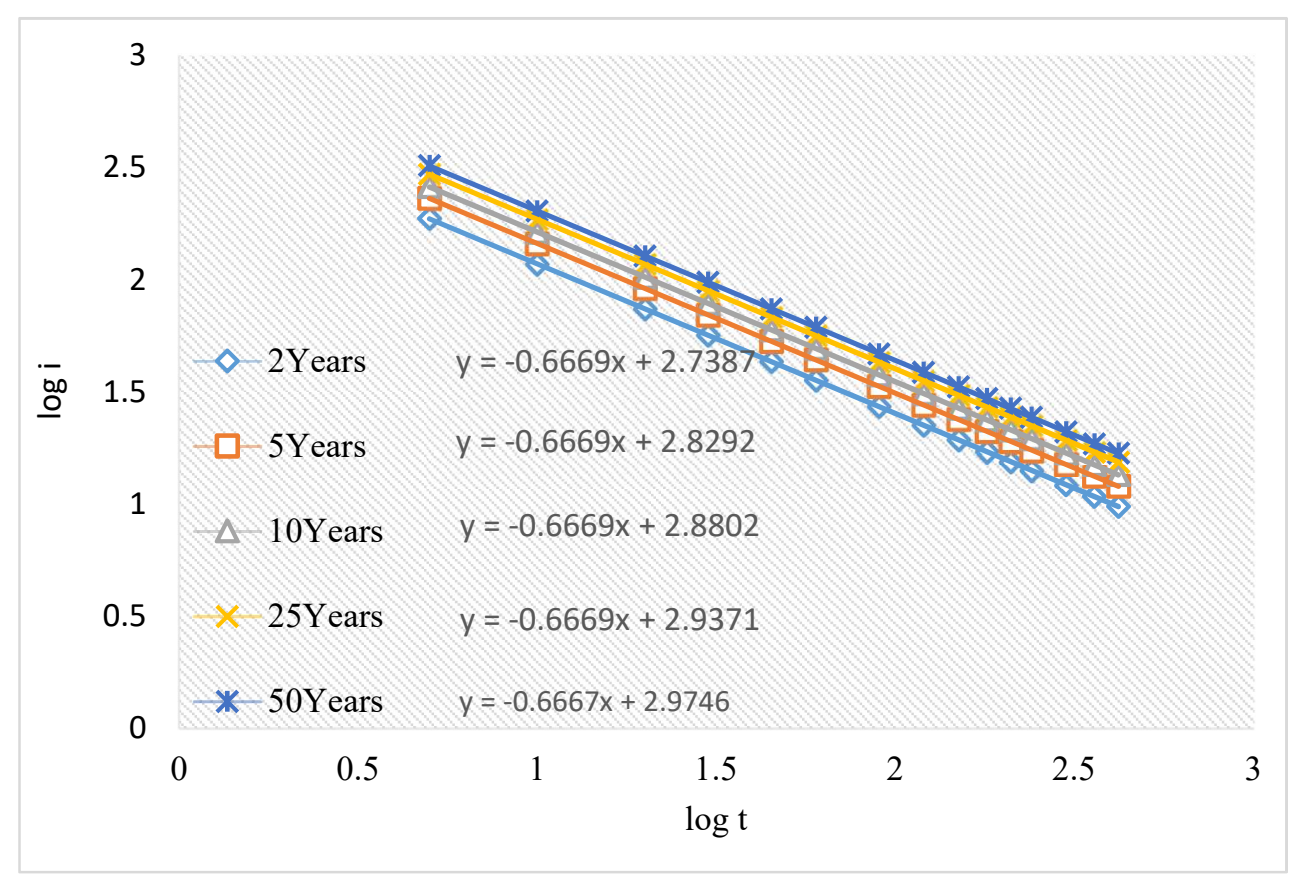

Figure 5: Determination of regional constant $e$ for Gumbel's distribution 
The regression equation for the curve in Figure 6 was compared with Equation (9) and the regional constant $m$ for Gumbel's distribution was determined from the gradient of the curve displayed in Figure 6 (i.e. 0.1664). Also, by comparing Equation (9) with the regression equation in Figure 6, it is glaring that the regional constant $c$ is equivalent to the antilog of the y-intercept of the curve in Figure 6. (i.e. $10^{2.7024}=$ 503.96).

The regional constants $c, m$ and $e$ for Pearson type (III) and Log-Pearson type
(III) distributions were determined in similar way, and were substituted into Equation (6) to obtain the IDF equation of the catchment for each distribution as shown in Table 6. The determined IDF equations were used to generate predicted rainfall intensities for the various durations in each return period, which were correlated with the observed rainfall intensities. The coefficients of determination $\left(R^{2}\right)$ of the correlation in each frequency distribution are shown in Table 6.

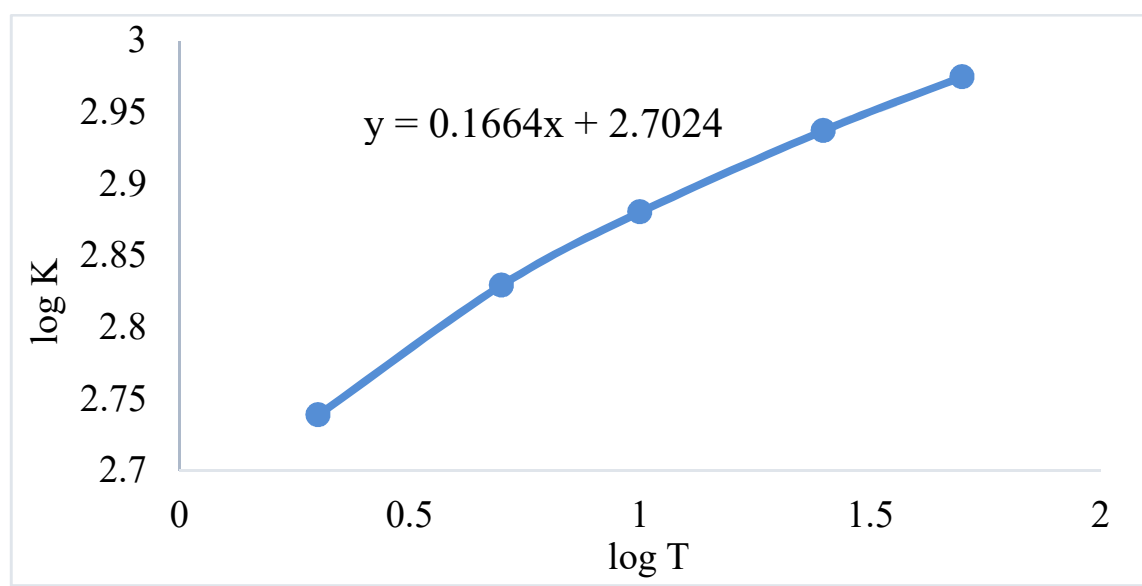

Figure 6: Determination of regional constants $c$ and $\boldsymbol{m}$ for Gumbel's distribution

Table 6: Regional constants and IDF equations of catchment for considered distributions

\begin{tabular}{|c|c|c|c|c|c|}
\hline Distribution & $c$ & $m$ & $\boldsymbol{e}$ & $i=\frac{c T^{m}}{t^{e}}$ & $R^{2}$ \\
\hline & & & & $503.96 T^{0.1664}$ & \\
\hline Gumbel & 503.96 & 0.1664 & 0.66686 & $t^{0.66686}$ & 0.9865 \\
\hline Pearson Type (III) & 517.37 & 0.1546 & 0.6669 & $i=\frac{517.37 T^{0.1546}}{t^{0.6669}}$ & 0.9766 \\
\hline & & & & $i=\underline{510.62 T^{0.1616}}$ & \\
\hline Log-Pearson Type (III) & 510.62 & 0.1616 & 0.66688 & $t^{0.66688}$ & 0.982 \\
\hline
\end{tabular}




\section{Discussion}

The curves in Figure 2, 3 and 4 revealed that high intensity rainfalls had shorter durations, which is a basic principle in hydrology. It was also noted that the intensities increase with return period which is in line with previous related research conducted by Mohammed et al. (2021), Majeed et al. (2021), Agarwal et al. (2021), Al-Wagdany (2020) and Gratein et al. (2019). Gumbel's distribution predicted same rainfall intensities with the observed data for the various durations during 2 years return period while Pearson type (III) and Log-Pearson type (III) predicted rainfall intensities slightly higher than the observed values during 2years return period. However, all the frequency distributions considered, predicted rainfall intensities slightly lower than the observed rainfall intensities during 5years, 25 and 50years return periods but slightly higher than observed intensities during 10years return period. Notwithstanding, there were no significant difference between the rainfall intensities predicted from all the IDF equations and those observed or recorded in the field, based on t-test analysis $(\mathrm{p}<0.01)$. Also, the correlation between the predicted intensities generated from these models (equations) and the observed intensities fitted well in their respective regression lines, with high $\mathrm{R}^{2}$ values ranging from $0.9766-0.9865$. In other words, the IDF equations developed to predict rainfall intensities of the catchment at any given return period and duration were highly reliable for all the frequency distributions considered (Gumbel, Pearson type III and Log-Pearson type III).

Nevertheless, the IDF equation for Gumbel's distribution is most reliable for the catchment as it has the highest $\mathrm{R}^{2}$ value (0.9865) compared to Pearson type (III) and Log-Pearson type (III) which are 0.9766 and 0.982 respectively. Nwaogazie and Sam (2019) also reported that Gumbel's distribution is more reliable than Pearson type (III) and Log-Pearson type (III) distribution for the catchment.

The Sherman's regional constants $c, m$ and $e$ for the catchment are 503.96, 0.1664 and 0.66686 for Gumbel; 517.37, 0.1546 and 0.6669 for Pearson type (III); 510.62, 0.1616 and 0.66688 for Log-Pearson type (III) correspondingly. These values negate the assertion of Nwaogazie and Sam (2019) that reported regional constants $c, m$ and $e$ for same catchment as 416.54, 0.2412 and 0.5613 for Gumbel; 479.458, 0.230 and 0.600 for Pearson type (III); 481.679, 0.300 and 0.654 for Log-Pearson type (III) in that order. The discrepancy could be attributed to the difference in sample size of the rainfall data since this research made use of 50years $(1971$ - 2020) rainfall data while the other utilized just 16years (1998-2013) data.

\section{CONLUSIONS AND RECOMMENDATIONS}

The research have provided highly reliable IDF equations that could be used to predict the rainfall intensities of Port Harcourt at different durations and return periods using Gumbel, Pearson type (III) and LogPearson type (III) distributions. Hence, it is recommended that the developed IDF models should be used when designing hydraulic structures such as surface drainages and culverts within Port Harcourt city and its environs, in order to minimize the flooding usually experienced in the city. However, priority should be given to the IDF equation developed for Gumbel's distribution since it has the best goodness of fit when correlated with observed data. It is also recommended that the Nigerian Meteorological Agency (NIMET) install automatic rain-gauge stations within Port Harcourt city. 


\section{REFERENCE}

Agarwal, S., Kumar, S. and Singh, U. K. (2021). Intensity Duration Frequency Curve Generation Using Historical and Future Downscaled Rainfall Data. Indian Journal of Ecology, 48(1): 275280.

Al-Wagdany, A. S. (2020). IntensityDuration-Frequency Curve Derivation from Different Rain Gauge Records. Journal of King Saud UniversityScience, 32: 3421-3431.

Echendu, A. J. (2021). Relationship between Urban Planning and Flooding in Port Harcourt City, Nigeria; Insights from Planning Professionals. Journal of Flood Risk Management. DOI: 10.1111/jfr3.12693.

Ede, A., Nwankwo, C. O., Oyebisi, S., Olofinnade, O., Okeke, A. and Busari, A. (2019). Failure Trend of Transport Infrastructure in Developing Nations: Case of Bridges Collapse in Nigeria. A Proceeding of $1^{\text {st }}$ International Conference on Sustainable Infrastructural Development: Material Science and Engineering Series. DOI: 10.1088/1757-899X/640/1/012102.

Gratein, T., Kundwa, M. J., Bakunzibake, P., Bunani, P. and Habyarimana, J. L. (2019). Development of Rainfall Intensity Duration Frequency (IDF) Curves for Hydraulic Design Aspect. Journal of Ecology and Natural Resources, 3(2): 1-14.
Majeed, A. R., Nile, B. K. and Al-Baidhani, J. H. (2021). Selection of Suitable PDF Model and Build of IDF Curves for Rainfall in Najaf City, Iraq. Journal of Physics: Conference Series, DOI: 10.1088/1742-6596/1973/1/012184.

Mohammed, A., Azumi, S. D., Modibbo, A. A. and Adamu, A. A. (2021). Development of Rainfall Intensity Duration Frequency (IDF) Curves for Design of Hydraulic Structures in Kano State, Nigeria. Platform-A Journal of Engineering, 5(2): 10-22.

Nwaogazie, I. L. and Agiho, G. C. (2019). Performance Analysis of Box and Circular Culverts Using HY 8 Software for Aluu Clan, Port Harcourt. Nigerian Journal of Technology, 38(1): 22-32.

Nwaogazie, I. L. and Duru, E. O. (2002). Development of Rainfall-IntensityDuration-Frequency Models for Port Harcourt City. NSE Technical Transaction, 37(2): 19-32.

Nwaogazie, I. L. and Sam, M. G. (2019). Probability and Non-Probability Rainfall Intensity-Duration-Frequency Modeling for Port-Harcourt Metropolis, Nigeria. International Journal of Hydrology, 3(1): 66-75.

Sule, J., Inuwa, I. A., Abdulahi, S. L. and Matawal, D. S. (2018). Bridge Collapse in Nigeria: A Case Study of Tatabu Bridge in Mokwa Local Government Area of Niger State. Civil Engineering Research, 10(8): 39-51. 